ACCEPTED VERSION - PLEASE CITE PUBLISHED VERSION AS:

Curran, F. C., \& Kitchin, J. (2018). Estimating the relationship between corporal punishment use and school suspensions: Longitudinal evidence from the Civil Rights Data Collection. Peabody Journal of Education, 93(2), 1-22.

\title{
Estimating the Relationship between Corporal Punishment Use and School Suspensions: Longitudinal Evidence from the Civil Rights Data Collection
}

\author{
F. Chris Curran, $\mathrm{PhD}$ \\ James Kitchin \\ UMBC School of Public Policy
}

\begin{abstract}
:
Corporal punishment use in school has decreased significantly over the past several decades; however, little research has explored the implications of such reductions in corporal punishment use. Theoretically, reducing or banning the use of corporal punishment could alter student and teacher behavior resulting in changes in rates of other forms of discipline such as suspension. Using nationally representative, longitudinal data from the Civil Rights Data Collection, this study estimates the relationship between corporal punishment use and suspension rates. Results from a series of fixed effects regression models suggest that reduced use or elimination of corporal punishment predicts lower rates of suspension overall but may predict higher rates of suspension in school districts serving larger proportions of racial minority students. Implications of these findings for current policy discussions around corporal punishment bans and for racial equity in school discipline are discussed.
\end{abstract}

\section{Acknowledgements:}

The authors are grateful for valuable research assistance by Katlyne Meade, for feedback from attendees at the 2017 meeting of the Association for Education Finance and Policy, and for feedback from the anonymous reviewers. 


\section{Introduction}

In recent years, punitive forms of school discipline, such as suspension and expulsion, have come under increasing criticism from policymakers, the media, and the broader public. Such disciplinary practices contrast with non-punitive forms of discipline such as restorative justice and positive behavioral interventions and supports that have gained traction in recent years. This shift represents a reversal of a several decades long trend in which school discipline law and policy increasingly emphasized severe, punitive, and exclusionary discipline (US Department of Justice \& US Department of Education, 2014; Curran, 2016a; 2016b) and has been driven in part by evidence of the potentially negative impacts of punitive discipline and the overrepresentation of racial minorities in such discipline (i.e. Gregory, Skiba, \& Noguera, 2010). While policy changes aimed at reducing the use of exclusionary discipline such as suspension have only recently begun to gain traction, another form of severe discipline, corporal punishment, has been experiencing reductions in use and outright policy prohibitions over the last four decades (Gershoff, Holas, \& Purtell, 2015).

Corporal punishment, or the infliction of physical punishment on students, represents one of the oldest forms of severe punishment in the school environment and has been upheld by the U.S. Supreme Court as a legal form of school discipline (Ingraham v. Wright, 1977; McCarthy, 2005; Russo, 2009). Over the last several decades, however, around thirty states have passed laws that prohibit the use of corporal punishment in the school environment (See Appendix Table A1; Gershoff et al., 2015). Nevertheless, corporal punishment is still practiced in a number of schools nationwide, particularly in the South, and has been shown to be disproportionately administered to students of color (Gershoff et al., 2015; Startz, 2016). Increased media attention and a letter from the former Secretary of Education, John B. King, to governors and chief state school officers calling for an end to the use of corporal punishment 
have renewed discussions of the banning of corporal punishment (King, 2016; Sparks \& Harwin, 2016).

Despite the wealth of attention to suspension and expulsion policies, corporal punishment has received significantly less attention in recent research literature. In particular, the implications of reducing or eliminating corporal punishment have been the subject of little research. Doing so is important for at least two reasons. First, the recent renewal in attention to corporal punishment may lead states and districts that have not banned the practice to consider bans. Second, banning or reducing the use of corporal punishment may, theoretically, have impacts on the use of other forms of punitive discipline such as suspensions. In particular, schools may experience changes in student behavior that result in differential use of suspensions, or schools may substitute the use of other forms of punishment, including suspension, for offenses that were previously assigned corporal punishment. Furthermore, given evidence that schools serving greater proportions of racial minorities, particularly Black students, tend towards more punitive disciplinary policies (Curran, 2017; Payne \& Welch, 2010; Welch \& Payne, 2010; 2012), changes in the use of suspension precipitated by changes in corporal punishment have the potential to differentially impact students of color.

The purpose of this study is to inform current policy debates regarding the use of corporal punishment in schools. In particular, we seek to understand the relationship between corporal punishment use and suspensions. To this end, we address the following research questions:

1) What is the relationship between school district use of corporal punishment and rates of suspension?

2) Does this relationship vary for students of different race/ethnicity?

3) Does this relationship vary by school district racial/ethnic composition? 
The findings of this paper provide some of the first evidence on the relationship between corporal punishment use and suspensions while also providing insight into the potential implications of banning corporal punishment. While limitations of our approach preclude causal estimates, our study nevertheless provides important insights given current policy efforts aimed at reducing the use of punitive disciplinary approaches such as corporal punishment and suspension.

We structure this paper as follows: First, we offer an overview of the theoretical mechanisms through which corporal punishment use might relate to suspension rates. Then, we describe the extant literature on corporal punishment in schools. We then turn to a presentation of our data and methodology. Finally, we present the results and discuss their relevance for policy and practice.

\section{Theory of Change}

Theoretically, changes in the use of one form of school discipline may affect the use of another through at least several different mechanisms (see Figure 1). First, changes in the use of corporal punishment, or an outright ban on its use, may result in changes in student misbehaver. Proponents of corporal punishment frequently cite its usefulness for maintaining order (Breem \& Goolsby, 2006, Aug 20; Gershoff et al., 2015; Medway \& Smiric, 1992). Teachers and schools that have relied on corporal punishment for many years may feel unequipped to use other disciplinary strategies. As a result, if the use of corporal punishment is reduced or banned, it is possible that student misbehavior could increase as teachers struggle with shifting their classroom management practices. On the other hand, however, a body of evidence points to the potentially harmful consequences of corporal punishment use and suggests that such use might actually exacerbate student misbehavior (Arif \& Rafi, 2007; Gershoff et al., 2015). If this is the case, then the removal of corporal punishment from the school environment could improve the 
school climate and the relationships between teachers and students thereby improving student behavior. Such changes in behavior, whether for the better or worse, could, in turn, translate to changes in the number of infractions that result in suspension.

In addition to potential changes in rates of misbehavior, corporal punishment bans or reductions may impact rates of suspensions through a substitution effect. Without corporal punishment at their disposal, teachers may rely on other forms of discipline as a response to behavioral infractions that previously would have resulted in corporal punishment. For instance, schools might adopt positive behavioral intervention and support systems or restorative justice practices that replace punitive or exclusionary forms of discipline with more positive alternatives (Gonzalez, 2015; Vincent, Sprague, Pavel, Tobin, \& Gau, 2015). Doing so, in turn, could result in the use of these forms of discipline in lieu of suspension or could result in changes in student behavior that result in shifts in suspension rates.

In addition to adopting such positive disciplinary approaches, schools could also directly substitute suspension for corporal punishment. While much is made of restorative and nonpunitive practices, many teachers may not be familiar with such approaches, may not feel equipped to implement them, or may not be supported with the necessary resources to do so. In contrast, suspension represents an established mechanism of discipline with which teachers have familiarity and for which structural supports are in place. Though corporal punishment is more likely than suspension to be viewed as a response to more minor offenses (tardiness, disrespect, etc.), there is evidence that the two disciplinary approaches do apply to the same offenses in some cases (Gagnon, Kennedy-Lewis, Gurel, 2014). In a study of Florida school using corporal punishment, school administrators reported using it and in-school suspension for similar offenses while also noting that it could be used in place of out of school suspension as well (Gagnon, Kennedy-Lewis, Gurel, 2014). Similarly, some school districts allow parents to opt their student 
out of corporal punishment but specify out of school suspension as the alternative consequence (Blevins Public Schools, 2014). Consequently, through such substitution, a decrease in the use of corporal punishment could result in increases in the use of suspensions, even if rates of student misbehavior remain unchanged.

\section{Prior Literature}

\section{Prevalence of Corporal Punishment}

It may come as a surprise to many that corporal punishment is still an allowable and used form of discipline in many of the nation's schools. The practice is currently legal in nineteen states (see Appendix Table A1) and, while banned by state laws in the other states and in some school districts, has been upheld by the United States Supreme Court as a legal form of school discipline (Ingraham v. Wright, 1977; McCarthy, 2005; Russo, 2009). Nevertheless, its use has been on the decline. In the late 1970 s and early 1980 s, approximately $4 \%$ of students experienced corporal punishment in a given school year; however, by the mid-2000s, less than $1 \%$ of students experienced corporal punishment (Gershoff et al., 2015). Though many states banned corporal punishment during this period, such bans generally occurred after the use of corporal punishment was nearly eliminated in each state (see Appendix B) making local school district actions the primary driver of reductions in corporal punishment. The strong tradition of local control on education issues may explain why many states wait until after districts discontinue the use of corporal punishment before passing a statewide ban.

Despite the substantial decrease in use over the last several decades, corporal punishment use nevertheless remains substantial in some regions. In many Southern states, corporal punishment remains common. For instance, in Mississippi, as many as $8 \%$ of students experience corporal punishment in a given year and approximately $55 \%$ of students attend schools where the practice is used (Adwar, 2014; Education Week, 2016; Gershoff et al., 2015). 


\section{Outcomes Associated with Corporal Punishment and Suspension}

Both corporal punishment and suspension have been shown to be associated with a number of undesirable outcomes for students. A number of studies have shown that the use of corporal punishment outside of the school environment, particularly by parents, is predictive of negative outcomes (Cheng, 2000; Gershoff, 2002). Likewise, though the number of studies examining the question are limited, experiencing corporal punishment within the school environment has also been linked to increased behavioral problems and decreased academic achievement (Arif \& Rafi, 2007).

Prior work has also shown that being suspended is predictive of lower academic achievement, an increased likelihood of dropping out or failing to attain a high school degree, and an increased likelihood of being involved with the juvenile justice system (Balfanz, Byrnes, \& Fox, 2015; Gregory, Skiba, \& Noquera, 2010; Shollenberger, 2015). Other work has shown that policies that promote the use of exclusionary discipline do not predict improvements in school-wide student behavior either, suggesting that the use of such discipline may harm individual students while providing little benefit to the broader school community (Curran, 2016a). Though prior work falls short of establishing causal links between suspension and negative student outcomes (Steinberg \& Lacoe, 2017), the preponderance of evidence suggests that both corporal punishment and suspension are potentially harmful practices for the students that experience these forms of discipline and that both approaches may have negative impacts for the broader school environment.

\section{Possible Changes in Behavior}

Given the negative outcomes associated with corporal punishment, efforts to reduce or ban its use are reasonable; however, as detailed in the theoretical framework, there are mechanisms through which reductions in corporal punishment could influence the use of other 
forms of discipline. First is the possibility that such reductions could result in changes in student behavior. Prior work suggests the possibility that student behavior may differ as a result of the use of corporal punishment. Using nationally representative data, Han (2010) documents that rural schools using corporal punishment experience fewer reported problem behaviors and less violent offenses than schools without corporal punishment but that such schools have greater incidents of insubordination. While not causal estimates, the results suggest that it is possible that student behavior may vary in response to the presence or absence of corporal punishment use. That the direction of the results varies across outcomes, however, provides less clear information on whether one would expect such changes to contribute to an increase or decrease in suspension rates.

The literature on the relationship between corporal punishment and changes in student behavior is sparse (Arif \& Rafi, 2007). This being the case, it is possible that the studies that explore this relationship in the home setting might be of use in understanding the relationship in public schools. Gershoff et al. (2015) provides an overview of the relevant literature and explains that in the home setting corporal punishment is not associated with an increase in desirable behavior. Rather it is associated with increased aggressive behavior and other unintended consequences (Gerhsoff et al., 2015). For example, a meta-analysis of 88 studies conducted over 62 years showed that while corporal punishment is associated with immediate compliance it is associated with later negative behavioral outcomes, including lower long-term compliance and increased child aggression (Gershoff, 2002). More recent studies have also confirmed the finding that increased corporal punishment is related to increased aggression (Gershoff et al., 2012; Lee et al., 2013). If the relationship between corporal punishment and changes in behavior is similar in the school setting as it is in the home setting, then decreasing its use in public schools could plausibly result in decreasing the instances of negative behavior that result in suspensions. 


\section{Possible Substitution}

In addition to possible behavioral changes, prior evidence also supports the possibility of substitution effects. Evidence from several school districts suggests that suspension may be used in lieu of corporal punishment when corporal punishment is banned (Evanac, 1993; Fasko et al., 1995; Russell, 1985). For instance, in one district, disciplinary reforms that included a curtailing of the use of corporal punishment were followed by a large increase in the use of suspensions (Russell, 1985). Similar increases in suspension rates were also found following a district-wide ban of corporal punishment in one Florida district (Evanac, 1993). Though these studies' designs did not allow for the establishment of a causal link between the two and were limited to single school districts, the increase in suspensions provides empirical support to the possibility that banning or reducing corporal punishment use could result in changes, particularly increases, in suspension rates.

\section{Racial/ethnic Disparities}

Finally, prior work on school discipline suggests that there is often heterogeneity in disciplinary outcomes across race/ethnicity (Anderson \& Ritter, 2017; Curran, 2016a; Gregory et al., 2010; Welch \& Payne, 2012). Indeed, evidence suggests that, in states that still allow corporal punishment, Black students, boys, and children with disabilities are at an elevated risk of experiencing corporal punishment (Gershoff \& Font, 2016; Sparks \& Harwin, 2016; Startz, 2016). Other evidence suggests that, when given the choice, racial minorities may be more likely to choose suspension over corporal punishment and that their likelihood of being in a district that allows corporal punishment may also vary (Florida State Dept. of Education, 1995; Russell, 1985).

In addition to the documented disparities in discipline use across race/ethnicity, there is also reason to believe that any changes in suspension in response to changes in corporal 
punishment use might vary based on the racial/ethnic composition of schools. Prior work has shown that schools and districts serving higher proportions of Black and Hispanic students are more likely to use zero tolerance and punitive forms of school discipline (Anderson \& Ritter, 2017; Curran, 2017; Payne \& Welch, 2010; Welch \& Payne, 2012). Welch and Payne (2010) argue that the higher rates of punitive disciplinary approaches in schools and districts serving high minority, particularly Black, student bodies is consistent with the racial threat hypothesis. The racial threat hypothesis suggests that greater proportions of racial minorities signal a threat to the power of the majority and prompt social control mechanisms, such as more punitive disciplinary environments, as a response (Welch \& Payne, 2010). This hypothesis and prior empirical evidence suggest the possibility that school districts serving greater proportions of minority students may respond differently, particularly with more punitive approaches, to changes in the use of corporal punishment than districts serving fewer minority students.

\section{Summary}

In summary, the prior literature suggests negative consequences of corporal punishment but also suggests that reductions in its use may have an impact on rates of suspension, which is itself linked to a number of undesirable outcomes. Furthermore, disparities in discipline across race/ethnicity suggest that such changes may vary by the racial/ethnic characteristics of students and districts. As a number of school districts and states consider curtailing or banning the use of corporal punishment, understanding the implications of such reductions or bans on suspension rates is important. To date, prior studies have not systematically explored this relationship. Consequently, this study makes a contribution by providing some of the first evidence on the relationship between corporal punishment use and rates of suspension.

\section{Data}


This study uses the restricted-use dataset of the Civil Rights Data Collection (CRDC) from the years 1980 to 2006. The CDRC was initiated in 1968 by the United States Department of Education's Office for Civil Rights (OCR). In general, the CRDC includes surveys of a random sample of public local education agencies (school districts) and schools approximately every two years. In most years, the CRDC includes a nationally representative sample of public school districts but occasionally includes a census in which data is collected from every public school district nationwide. In the time-period we are interested in, the CRDC conducted a census only in 2000 . The CRDC has very high response rates. In 2006 , the data is based off a sample of 6,000 school districts, with a response rate of $100 \%$, and 60,000 schools, with a response rate of $99.6 \%$ (Department of Education, 2017). The 2000 census was comprised of 14,716 school districts and 88,882 schools. Relevant to this study, the CRDC provides data on the number of students that experienced corporal punishment in each district as well as the number of students that each district suspended each survey year, both overall and disaggregated by student race/ethnicity.

Corporal punishment use was first recorded by the CDRC in 1976, however the corporal punishment data from the first couple iterations of the survey were unreliable and included large amounts of missing data. We therefore start our analysis with the 1980 survey, an approach that is consistent with prior work examining corporal punishment with this data (Gershoff et al., 2015). Due to changes in the collection of suspension data by student race in the late 2000s that prevents consistent comparisons with earlier years, we use data through the year 2006. We include in our analysis all 14 CRDC survey waves from 1980 to 2006 resulting in an analytic sample size of 59,040 school district by year observations (rounded to nearest 10 to comply with IES restricted data requirements). 
A limitation of the CDRC is that there is no way to account for the possible effect that different reporting practices across school districts might have on the consistency of the data. For example, the CRDC states their data represent the number of students that received corporal punishment (or were suspended) in each year. However, it is conceivable that some districts might have reported the number of times students received corporal punishment, and if a student received it more than once, this could influence the data and therefore our results. This focus on the number of students that received corporal punishment (or were suspended) underreports the actual use of these practices in that some students likely received them more than once. Another limitation of the dataset is that it does not include the number of students in each district that qualify for free or reduced-price lunch or any other indicator of socio-economic status.

\section{Independent Variables}

The main explanatory variable is the presence of a "de facto" ban on corporal punishment in a school district. We treated school districts that reported a corporal punishment rate of zero in a survey year as having banned the use of corporal punishment in practice, even if it was technically still legal in that state. We created a variable representing the proportion of students that received corporal punishment by dividing, for a given year, the number of students that were reported to have received corporal punishment by the total number of students enrolled for each school district. There were some instances in which this proportion was greater than one. We attributed this to a reporting error on the part of the school district filling out the survey or a manual input error by either the school district or the CRDC. We used case-wise deletion to remove the approximately 10 (rounded to comply with IES standards) observations for which the proportions were greater than one from our data. We then coded a binary "de facto" ban variable that was equal to " 1 " if a district reported a corporal punishment rate of zero in a survey year and equal to " 0 " if they reported a rate greater than zero. This variable is time-varying in that it could 
start at "1" move to " 0 " and then back to "1" again, which reflects the possibility that districts stop the use of corporal punishment (perhaps as a given school board or superintendent changes policy) and then could subsequently change that policy and resume the use of the practice. Though this "de facto" ban indicator does not necessarily represent a formal policy ban on corporal punishment by a school district, we found that, among districts that were observed more than once in the data, approximately $90 \%$ of districts that reported zero instances of corporal punishment in a given year reported no use of corporal punishment in subsequent years.

In addition to the "de facto" ban indicator, we also estimated models in which we used the proportion of students receiving corporal punishment in each district as the explanatory variable. The use of the rate of corporal punishment as an independent variable in lieu of the "de facto" ban indicator allowed for identification of relationships from variation in the rate of corporal punishment, even in cases where districts did not entirely eliminate its use.

\section{Dependent Variables}

The main dependent variable is the district-level suspension rate. We coded this by dividing the number of students suspended in each district in each survey-year by the total number of students enrolled in each district in that same year. We also created White, Black, and Hispanic suspension rates by dividing the number of students of those racial groups that were suspended in each district in each survey-year by the number of students of those racial groups enrolled in each district in the same year. We used these racial suspension rates as dependent variables in subsequent analyses. As with the corporal punishment rate, there were some districts in which the proportion was greater than one $(<1 \%)$ and we dropped these from our analysis.

\section{Control Variables}

We control for a number of time-variant school district characteristics available in the CRDC. For each survey year, these include: the natural log of the total number of students 
enrolled in each school district, total number of schools in each school district, the proportion of enrolled students that were Black, Hispanic, Asian, or Native American, and the proportion of total enrollment that females accounted for. We handled missing observations in any of the covariates by case-wise deletion.

\section{Methods}

In our primary models, we used ordinary least squares regression to explore the relationship between a "de facto" ban on corporal punishment and suspensions at the district level. Our primary model was:

$$
\begin{aligned}
\text { SuspensionRate }_{s j y}= & \beta_{0}+\beta_{1} \text { DeFactoBan }_{s j y}+\beta_{2} \text { TotalEnrollment }_{s j y}+\beta_{3} \text { TotalSchools }_{s j y} \\
& +\beta_{4} \text { RacialProportions }_{s j y}+\beta_{5} \text { FemaleProportion }_{s j y}+\delta_{s j y}+\varepsilon_{s j y}
\end{aligned}
$$

where SuspensionRate is the proportion of students in district $j$ in state $s$ that were suspended at least once in year $y$, DeFactoBan is a binary indicator where " 1 " means that district $j$ did not use corporal punishment in year $y$, TotalEnrollment is the natura log of the total number of students enrolled in district $j$ in state $s$ in year $y$, TotalSchools is the number of schools in district $j$ in state $s$ in year $y$, RacialProportions is a series of covariates representing the proportion of the students in district $j$ in state $s$ that are Black, Asian, Hispanic, or Native American in year $y$, FemaleProportion is the proportion of students in district $j$ in state $s$ that are female in year $y$, and $\delta$ represents a series of year, state, state by year, and/or school district fixed effects. In this model, $\beta_{1}$ can be understood as the relationship between a "de facto" corporal punishment ban and the district level suspension rate after accounting for the observable covariates and fixed characteristics of states, districts, or years accounted for through the fixed effects.

We estimated versions of model 1 in which we changed the dependent variable to the proportion of White students suspended, the proportion of Black students suspended, and the 
proportion of Hispanic students suspended. In these specifications, we limited the sample to districts that had more than 20 students of that race enrolled. For example, when the rate of Black students suspended was the dependent variable we only included school districts that had greater than 20 Black students. This restriction was put in place in order to ensure that estimates were not driven by districts with insufficiently sized subgroups and is consistent with approaches taken in prior literature (Van Matre, Shores, Kalogrides, \& Reardon, 2016).

We then estimated a model in which the proportion of students experiencing corporal punishment replaced the "de facto" ban indicator as the main independent variable. This revised model took on the following form:

$$
\begin{aligned}
\text { SuspensionRate }_{s j y}= & \beta_{0}+\beta_{1} \text { CorporalPunishmentRate }_{s j y}+\beta_{2} \text { TotalEnrollment }_{s j y}+ \\
& \beta_{3} \text { TotalSchools }_{s j y}+\mathrm{B}_{4} \text { RacialProportions }_{s j y}+\beta_{5} \text { FemaleProportion }_{s j y} \\
& +\delta_{s j y}+\varepsilon_{s j y}
\end{aligned}
$$

in which covariates and fixed effects are the same as in model 1. As with model 1, we also estimated versions of model 2 that predicted suspension rates by race/ethnicity.

Finally, we explored the degree to which the racial composition of a school district moderated the relationship between corporal punishment and suspension rates. We interacted the "de facto" corporal punishment ban indicator with the proportions of racial/ethnic minorities enrolled in each district and added these interactions to model 1. Likewise, we then interacted the corporal punishment rate with the racial enrollment proportions and added these interactions to model 2 .

A primary concern with this and any observational study is the threat of omitted variable bias. In particular, it is possible that school districts that eliminated the use of corporal punishment or changed the rate at which they used corporal punishment may be different from 
those districts that did not make such changes. To the extent that these differences are systematically related to both the independent and dependent variables of the study, they will bias estimates of the effect of corporal punishment use on suspension use.

Our empirical strategy attempts to account for as many sources of such endogeneity as possible by controlling for observable characteristics of districts and accounting for unobservable fixed aspects of years, states, state by years, or school districts. For instance, the state fixed effects control for any time-invariant aspects of school districts in the same state, such as being located in a particular region of the country. Similarly, the state by year fixed effects control for any fixed aspects of districts in the same state in the same year, such as the political party of the state governor in that particular year. The school district fixed effects control for any fixed aspects of school districts over time; however, given that the data is of a repeated cross-sectional nature rather than panel data, it is limited by the fact that many districts only appear in the dataset once $(3,280)$ and others appear only two or three times $(5,290)$ in many cases separated by several decades of time. We believe that this specification is important as it controls for the most amount of unobserved characteristics, but acknowledge that the non-uniform appearance of school districts over time limit the utility of this model. Consequently, we focus on both the state by year fixed effects model and the district fixed effects model as our fully specified models.

While these approaches account for a number of threats to the internal validity of the study, they do not preclude all sources of omitted variable bias. In particular, unobservable characteristics of districts that vary over time and within state may still be unaccounted for by the model. Also, like most studies of school discipline, we cannot directly observe the general level of student misbehavior which would be a useful measure to control for or examine as a mediator. Furthermore, as previously noted, the dataset did not have indicators of student poverty and so 
we were unable to control for that as well. Consequently, the results of the study should be interpreted as covariate adjusted relationships rather than definitive causal estimates.

\section{Results}

Across models, we find that, on average, lower rates of use (including "de facto" bans) of corporal punishment are related to lower rates of suspension use. However, we find that this overall relationship masks significant heterogeneity in the relationship across school districts. In particular, we find suggestive evidence that lower levels of corporal punishment use may actually be related to higher rates of suspension use in school districts that serve student bodies that have higher proportions of Black or Hispanic students. In this section, we present results that support each of these findings.

\section{Descriptive results}

Table 1 presents means and standard deviations for the key independent, dependent, and control variables used in all of the analyses for a select number of years. As shown, the average rate of corporal punishment use is relatively low. Across all years in the data, the average school district administered corporal punishment to slightly fewer than $3 \%$ of the districts' students in a given year. Over time, the frequency of corporal punishment use has decreased, from an average of approximately $3.6 \%$ of students in a district in 1980 to approximately one and a half percent of students by the mid-2000s. Relatedly, the proportion of districts reporting no use of corporal punishment has approximately doubled from 1980 to the mid-2000s, increasing from under $40 \%$ of districts in 1980 to nearly $80 \%$ of school districts in 2004 .

In comparison, the use of suspension is slightly more common than that of corporal punishment across the full dataset though it is still a relatively infrequent practice with the average district suspending less than $5 \%$ of its students in any given year. The average rate of suspension for school districts has increased by about $40 \%$ over the time frame of the data 
though, from approximately $4 \%$ of students in 1980 to $5.5 \%$ in 2004 . As would be expected from prior research, there are wide disparities in the rates of suspension use across student race/ethnicity. On average, the rate of suspension for Black students is about twice as large as the rate of suspension for White students.

Interestingly, our descriptive analyses revealed little relationship between state bans of corporal punishment and rates of corporal punishment use. While one might expect such state bans to offer an abrupt and potentially exogenous source of variation in changes in corporal punishment use, we found that in almost all cases the state bans were put in place after districts within the states virtually eliminated or reduced to near zero the use of corporal punishment. The figures in Appendix B show the average district corporal punishment rate for districts in states that passed a ban at some point during our study's time frame (1980 to 2006). The vertical lines represent the year that the state ban was passed. As shown, state bans were generally put in place after reduction or elimination of the use of corporal punishment in the state. For example, although Rhode Island passed a state-wide corporal punishment ban in 2002, the practice had not been used, due to decisions at the district level, in the state since 1977 (Rhode Island Department of Elementary and Secondary Education, personal communication). Additional analyses (not shown) including state and year fixed effects which modeled the relationship between a state ban of corporal punishment and rates of corporal punishment found that the state bans were not predictive of decreases in corporal punishment use (as the use of the practice was already virtually eliminated by district actions when the state bans were passed).

\section{Relationship between corporal punishment use and suspension}

We turn next to models that examine the relationship between corporal punishment use and suspension use. As detailed in the methodology section, we explore this relationship in two ways. First, we model the relationship between suspension rates and a "de facto" district ban 
(districts reporting no use of corporal punishment). Given that state bans were unrelated to reductions in corporal punishment use, the modeling of district level "de facto" bans captures the changes, such as explicit district level bans or non-use, which have actually reduced corporal punishment use. In the second set of models, we estimate the relationship between the rate of corporal punishment use and suspension rates, capturing relationships when corporal punishment use is lower though not entirely eliminated.

Panel 1 of Table 2 shows results from models predicting the district suspension rate from the binary indicator of a district not using corporal punishment ("de facto" ban). Column 1 shows the bivariate regression while the subsequent columns add year fixed effects, state fixed effects, state by year fixed effects, time-varying district characteristics, and district fixed effects. We focus on the results of the models with state by year plus observable covariates (column 5) and those with district fixed effects (column 6) as our fully specified models. While the use of the district fixed effect addresses more potential sources of omitted variable bias, the estimates depend on variation from districts that were observed multiple times in the dataset which only occurs for districts that happened to be randomly sampled at multiples waves of the CRDC.

As shown in both the bivariate and the fully specified models, districts that do not report the use of corporal punishment have a lower rate of suspension use. In particular, districts that do not use corporal punishment suspend about a tenth to a fifth of a percentage point fewer students even after accounting for observable characteristics of the districts and unobservable, fixed state by year characteristics or time-invariant district characteristics.

The bottom panel of Table 2 shows results from models predicting the proportion of students experiencing suspension from the rate of corporal punishment use in the district. As shown, the results suggest that districts that have higher rates of corporal punishment tend to, on average, also have higher rates of suspension. This is true in both the bivariate regression 
(column 1) as well as the fully specified models (columns 5 and 6). In short, then, results from models using the "de facto" corporal punishment ban indicator and results from models using the rate of corporal punishment both suggest that reductions or elimination of corporal punishment are associated with lower levels of suspension.

\section{Racial subgroups}

Though results from models estimating the relationship between corporal punishment and suspension suggest that lower levels of one predict lower levels of the other, it is possible that this relationship is not experienced equally by all students. In Table 3, we show results from the fully specified models, those containing state by year fixed effects and observable covariates as well as those including district fixed effects, for outcomes of suspension rates of White, Black, and Hispanic students. As shown, the results suggest that there might be heterogeneity in the relationship between corporal punishment rates and suspension rates. In particular, as shown in Panel 1 of Table 3, the "de facto" corporal punishment ban indicator is related to lower levels in the suspension rate for White students but no significant differences in the rate of suspension for Black or Hispanic students. Also, as shown in Panel 2 of Table 3, lower levels of corporal punishment use are associated with lower suspension rates for both White students and Black students but not for Hispanic students.

\section{School district racial composition}

To further probe the role of race and the differential relationships with suspension rate by race, we estimated models that interacted the indicators of corporal punishment use with the proportion of Black and Hispanic students in the school district. These models speak to the racial threat hypothesis which emphasizes the role of district racial composition (Welch \& Payne, 2010). Table 4 shows results from models predicting the overall suspension rate and suspension rates by racial/ethnic subgroup from the indicators of corporal punishment use and 
the interactions with school district racial composition. In Panel 1 of Table 4, we show that, though corporal punishment bans are related to lower overall suspension rates, in districts with higher proportions of Black or Hispanic students, not using corporal punishment is actually related to higher rates of suspension. This is particularly the case in the specification state by year fixed effects (columns 3, 5, and 7), however some of the statistical significance is lost for Black students and the results become inconclusive for White and Hispanic students when looking at the specifications that use district fixed effects (columns 4, 6, and 8). Similarly, in districts with higher proportions of Black or Hispanic students, lower rates of corporal punishment use tend to be related to higher rates of suspension though this result is less conclusive in the district fixed effects models and is inconclusive for Hispanic students (see Panel 2 of Table 4). Notably, these relationships are seen for racial minority students and White students attending school districts that serve predominantly minority student bodies.

\section{Summary of findings}

Overall, the non-use of or reduced use of corporal punishment appears to be related to lower levels of suspension. This relationship, however, masks important heterogeneity by student race and school district racial composition. The results suggest that this overall lower level of suspension is driven predominantly by lower levels of suspension in school districts serving predominantly White student bodies. Furthermore, in districts serving higher percentages of Black or Hispanic students, non-use and lower rates of corporal punishment appear to be related to higher rates of suspension use.

\section{Discussion}

Many school districts and states have recently begun conversations about the elimination of corporal punishment as a method of student discipline. Though our results suggest that, by and large, state bans have generally had much less impact than district bans, the consideration of 
such bans is nevertheless laudable given the lack of evidence of positive effects of corporal punishment. That said, our findings suggest that school districts and states should carefully consider and plan for the potential unintended consequences of eliminating corporal punishment use in schools. In particular, they should anticipate and seek to address potential heterogeneity in outcomes for students of color and districts serving greater proportions of such students. In this section, we put our findings and implications in the context of prior literature and current policy debates.

Of particular interest to policymakers and reformers discussing ways to curtail the use of corporal punishment in schools is the finding that state bans of corporal punishment have, in general, had little impact on the use of corporal punishment. In particular, our descriptive findings suggest that the vast majority of state bans on corporal punishment occurred after such time that almost all districts in the state had eliminated the use of corporal punishment. In fact, the passage of a state ban was only visibly related to a reduction in corporal punishment use in a handful of states and, even in these states, the level of use was already quite low. This finding has implications for prior research that found no relationship between such state bans and juvenile justice outcomes, suggesting that the lack of relationship may be due to a lack of actual changes in disciplinary practices as a result of the bans (Gershoff et al., 2015). Furthermore, this finding suggests that advocates working to reduce the use of corporal punishment may find more traction in reducing and banning corporal punishment at the local district level prior to pushing for state level bans in states where the practice is still common.

Regardless of the level of governance at which bans or reductions are advocated for, the findings suggest that attention must be given to the possible impacts on the use of other forms of discipline, such as suspension. On the one hand, our findings suggest that, in aggregate, lower levels or non-use of corporal punishment are related to lower levels of suspension. It is possible 
that reducing or eliminating the use of corporal punishment may improve school climate and student relationships with teachers in ways that translate to improved student behavior and fewer disciplinary infractions (Arif \& Rafi, 2007). In this regard, curtailing the use of corporal punishment may have broader positive impacts beyond reduced use of physical punishment.

However, importantly, our results suggest that this potential benefit may not be uniformly experienced. Rather, the lower rate of suspension is largely related to lower rates of the suspension of White students (and in schools serving higher percentages of White students) as opposed to racial/ethnic minority students (and students in schools serving greater percentages of minorities). Furthermore, in school districts serving larger proportions of Black or Hispanic students, lower rates of corporal punishment use actually predict higher rates of suspension. These findings fit within a body of prior literature that has demonstrated greater use of punitive and exclusionary disciplinary practices, including suspension, in schools and districts serving greater proportions of Black and Hispanic students (Curran, 2017; Payne \& Welch, 2010; Welch \& Payne, 2012). Given that such environments are more likely to be using exclusionary disciplinary policies, such as zero tolerance and suspension, it makes sense that they would be more likely to shift to greater use of suspension as they reduce corporal punishment use.

That the reduction or elimination of corporal punishment may influence the use of another form of exclusionary discipline, namely suspension, suggests the importance of implementing and supporting alternative approaches to discipline. Fortunately, various alternatives to punitive and exclusionary discipline have gained traction in recent years and have shown promise for improving disciplinary outcomes. For instance, school wide positive behavioral interventions and supports, which emphasize consistent school-wide behavioral expectations and couple them with positive reinforcement for acceptable behavior, have been shown through randomized control trials to reduce the frequency of punitive discipline 
(Bradshaw, Mitchell, \& Leaf, 2010; Horner et al., 2009). Similarly, restorative justice practices, which focus on community building and the restoration of community when harms occur, have shown some promise in improving educational outcomes and decreasing punitive discipline though these studies rely on weaker designs (Baker, 2008; Gonzalez, 2015; Morrison, 2007). In another example, experimental evidence suggests that teacher professional development which emphasizes improving teachers' emotional support, instructional capacity, and classroom practices can improve behavioral outcomes and reduce racial disparities in discipline (Gregory, Allen, Mikami, Hafen, \& Pianta, 2016).

While promising alternatives to corporal punishment and suspension exist, each of these alternatives are not without costs for implementation. In particular, in school districts where corporal punishment has been a regularly used component of the discipline system, teachers and principals may require additional resources such as training in such alternative approaches to discipline, additional staff with expertise in counseling or non-punitive discipline, or supports for implementing school-wide interventions. Prior work suggests that such resources are not always present and that sufficient time for implementation of new practices is not always available (Abdal-Haqq, 1996). For instance, recent data suggests that one in five high schools lack school guidance counselors (U.S. Department of Education Office for Civil Rights, 2014). This suggests then, that as schools curtail the use of or eliminate the use of corporal punishment, it is critical to provide school administrators and teachers with the training, time, and resources to implement positive alternatives to both corporal punishment and suspension.

\section{Limitations}

While this study provides some of the first empirical evidence regarding the potential implications of reducing or banning corporal punishment use, it is not without its limitations. The primary limitation of this study is its inability to draw definitive causal estimates of the 
effects of banning or reducing corporal punishment. While the empirical design attempts to control for a number of potential confounders through the use of observable covariates and a variety of fixed effects, it nevertheless remains possible that the "de facto" bans or changes in the rate of corporal punishment remain correlated with unobservable characteristics of school districts that vary across time and within state. For instance, if a school district banned corporal punishment while simultaneously implementing a positive behavior support system, the presence of the PBIS system would be unaccounted for by the current empirical models. We were also unable to control for the general level of student misbehavior or for the socio-economic status of the students. Consequently, the results of the study should be interpreted as covariate adjusted relationships that, while suggestive of possible causal relationships, are not definitive causal estimates. Nevertheless, the results push beyond the current state of the literature by providing some of the first evidence on the question addressed and attempting to mitigate endogeneity through the use of a robust set of controls and fixed effect models. As such, this study lays the groundwork for future work on the impacts of reducing corporal punishment use in schools.

\section{Conclusion}

Corporal punishment remains a controversial form of school discipline that, despite experiencing reductions in use over the last several decades, is still a prominent component of many school environments. Recent attention to corporal punishment has renewed efforts to ban the practice; however, prior to this study, little research had systematically explored the implications of doing so. Though there is little evidence of benefits from corporal punishment use and some evidence of harms, the results of this study have suggested that policy changes that reduce or eliminate the use of corporal punishment might result in increases in an exclusionary form of school discipline, namely suspension, for disadvantaged groups of students and school districts serving such students. As advocates and policymakers continue work to reduce the use 
of corporal punishment, attention should be given to such potential negative outcomes, and proactive steps should be taken to ensure that reductions in the use of corporal punishment result in educational benefits for all students. 


\section{References}

Abdal-Haqq, I. (1996). Making time for teacher professional development. ERIC Digest.

Adwar, C. (2014, March 28). These are the 19 States that Still Let Public Schools Hit Kids. Business Insider. Retrieved from: http://www.businessinsider.com/19-states-still-allowcorporal-punishment-2014-3.

Anderson, K.P. and Ritter, G.W. (2017). Disparate Use of Exclusionary Discipline: Evidence on Inequities in School Discipline from a U.S. State. Education Policy Analysis Archives, 25(49), 1-36.

Arif, M. S., \& Rafi, M. S. (2007). Effects of Corporal Punishment and Psychological Treatment on Students' Learning and Behavior. Journal of Theory and Practice in Education, 3(2), 171-180.

Baker, M. L. (2008). DPS restorative justice project: Executive summary, 2007-2008.

Balfanz, R., Byrnes, V., Fox, J. (2015). Sent home and put off track: The antecedents, disproportionalities, and consequences of being suspended in the $9^{\text {th }}$ grade. In D. J. Losen (Ed.), Closing the School Discipline Gap: Equitable Remedies for Excessive Exclusion. (pp. 17-30). New York, NY: Teachers College Press.

Blevins Public Schools. (2014). Student Handbook. Retrieved from: http://blevinshornets.weebly.com/uploads/4/9/1/2/4912699/2014-15_handbook.pdf

Bradshaw, C. P., Mitchell, M. M., \& Leaf, P. J. (2010). Examining the effects of schoolwide positive behavioral interventions and supports on student outcomes results from a randomized controlled effectiveness trial in elementary schools. Journal of Positive Behavior Interventions, 12(3), 133-148.

Breem, K. \& Goolsby, K. (2006, Aug 20). Some north Texas school districts are holding fast to corporal punishment, but critics say they're out of whack. Dallas Morning News. 
Cheng, K. O. (2000). Review of the Literature Regarding the Short-and Long-Term Consequences of Corporal Punishment on Children. Doctoral Dissertation: Biola University.

Curran, F.C. (2016a). Estimating the effect of state zero tolerance laws on exclusionary discipline, racial discipline gaps, and student behavior. Educational Evaluation and Policy Analysis, 38(4), 647-668.

Curran, F.C. (2016b). Racial Disproportionalities in Discipline: The Role of Zero Tolerance Policies. Critical Examinations of School Violence and Disturbance in K-12 Education, 149.

Curran, F.C. (2017). The law, policy, and portrayal of zero tolerance school discipline: Examining prevalence and characteristics across levels of governance and school districts. Educational Policy. Online First.

Department of Education. (2017). Civil Rights Data Collection, 2006. Retrieved from: https://catalog.data.gov/dataset/civil-rights-data-collection-2006

Education Week (2016, August 23). Is Corporal Punishment an Option in Your State? Education Week. Retrieved from: http://www.edweek.org/ew/section/multimedia/states-bancorporal-punishment.html?cmp=eml-eb-sr-corporal-20160823.

Fasko, D. et al. (1995). An analysis of disciplinary suspensions. Paper presented at the Annual Meeting of the Mid-South Educational Research Association. Biloxi, MS.

Florida State Dept. of Education. (1995). Florida School Discipline Study: 1994 Juvenile Justice Reform Act. A Report to the Florida Legislature. (121). Tallahassee, FL.

Gagnon, J. C., Kennedy-Lewis, B. L., \& Gurel, S. (2014). Corporal punishment in Florida schools. Retrieved from: 
https://www.splcenter.org/sites/default/files/d6_legacy_files/downloads/publication/corp oral_punishment_fl_2014_final.pdf

Gershoff, E. T. (2002). Corporal punishment by parents and associated child behaviors and experiences: a meta-analytic and theoretical review. Psychological Bulletin, 128(4), 539.

Gershoff, E. T., \& Font, S. A. (2016). Corporal Punishment in US Public Schools: Prevalence, Disparities in Use, and Status in State and Federal Policy. Social Policy Report, 30(1).

Gershoff, E. T., Holas, I., \& Purtell, K.M. (2015). Corporal Punishment in U.S. Public Schools: Legal Precedents, Current Practices, and Future Policy. New York, NY: Springer.

Gershoff, E. T., Lansford, J. E., Sexton, H. R., Davis-Kean, P., \& Sameroff, A. J. (2012). Longitudinal Links Between Spanking and Children's Externalizing Behaviors in a National Sample of White, Black, Hispanic, and Asian American Families. Child Development, 83(3), 838-843.

Gonzalez, T. (2015). Socializing schools: Addressing racial disparities in discipline through restorative justice. In D. J. Losen (Ed.), Closing the School Discipline Gap: Equitable Remedies for Excessive Exclusion. (pp. 151-165). New York, NY: Teachers College Press.

Gregory, A., Skiba, R. J., \& Noguera, P. A. (2010). The achievement gap and the discipline gap: Two sides of the same coin?. Educational Researcher, 39(1), 59-68.

Gregory, A., Allen, J. P., Mikami, A. Y., Hafen, C. A., \& Pianta, R. C. (2015). The promise of a teacher professional development program in reducing racial disparity in classroom exclusionary discipline. In Losen (Ed.), Closing the School Discipline Gap, 166-179.

Gundersen Center for Effective Discipline (n.d.). State Laws. Gundersen Center for Effective Discipline. Retrieved from: http://www.gundersenhealth.org/ncptc/center-for-effectivediscipline/discipline-and-the-law/state-laws/ 
Horner, R. H., Sugai, G., Smolkowski, K., Eber, L., Nakasato, J., Todd, A. W., \& Esperanza, J. (2009). A randomized, wait-list controlled effectiveness trial assessing school-wide positive behavior support in elementary schools. Journal of Positive Behavior Interventions, 11(3), 133-144.

Ingraham v. Wright, 430 U.S. 651 (1977)

King, J.B. (2016). Letter to States Calling for an End to Corporal Punishment in Schools. U.S. Department of Education. Retrieved from: https://www2.ed.gov/policy/gen/guid/schooldiscipline/files/corporal-punishment-dcl-11-22-2016.pdf

Lee, S. J., Altschul, I., \& Gershoff, E. T. (2013). Does warmth moderate longitudinal associations between maternal spanking and child aggression in early childhood?. Developmental Psychology, 49(11), 2017-2028. doi:10.1037/a0031630

McCarthy, M. M. (2005). Corporal Punishment in Public Schools: Is the United States Out of Step?. Educational Horizons, 83(4), 235-240.

Morrison, B. (2007). Restoring safe school communities: A whole school response to bullying, violence and alienation. Sydney, Australia: Federation Press.

Payne, A. \& Welch, K. (2010). Modeling the effects of racial threat on punitive and restorative school discipline practices. Criminology, 48(4), 1019-1062.

Rhode Island Department of Elementary and Secondary Education. Personal Communication. September 26, 2016.

Russell, W. C. (1985). Litigation and the Policy Process: The Impact of" Stevenson V. Jefferson County Public Schools" on Racially Disproportionate Suspension. ERIC Clearinghouse.

Russo, C. J. (2009). "Spare the Rod and Spoil the Child?" The Law and Corporal Punishment. School Business Affairs, 75(10), 30-32. 
Shollenberger, T.L. (2015). Racial disparities in school suspension and subsequent outcomes: Evidence from the National Longitudinal Survey of Youth. In D. J. Losen (Ed.), Closing the School Discipline Gap: Equitable Remedies for Excessive Exclusion. (pp. 31-43). New York, NY: Teachers College Press.

Sparks, S.D. \& Harwin, A. (2016, August 23). Corporal punishment use found in schools in 21 states. Education Week. Retrieved from: http://www.edweek.org/ew/articles/2016/08/23/corporal-punishment-use-found-inschools-in.html

Startz, D. (2016). Schools, black children, and corporal punishment. Brown Center Chalkboard. Brookings Institute. Retrieved from: https:/www.brookings.edu/blog/brown-centerchalkboard/2016/01/14/schools-black-children-and-corporal-punishment/

Steinberg, M. P., \& Lacoe, J. (2017). What Do We Know About School Discipline Reform?. Education Next, 17(1).

Thomson Reuters (n.d.). State Laws Regarding Corporal Punishment. FindLaw. Retrieved from: http://education.findlaw.com/student-conduct-and-discipline/state-laws-regardingcorporal-punishment.html?version=2

U.S. Department of Education Office for Civil Rights (2014). Civil Rights Data Collection data snapshot: Teacher equity. Issue Brief No. 4. Retrieved from: https://www2.ed.gov/about/offices/list/ocr/docs/crdc-teacher-equity-snapshot.pdf

U.S. Department of Justice \& U.S. Department of Education (2014). Notice of language assistance: Dear colleague letter on the nondiscriminatory administration of school discipline. Retrieved from: https://www2.ed.gov/about/offices/list/ocr/letters/colleague201401-title-vi.pdf 
Van Matre, J., Shores, K., Kalogrides, D., Reardon, S. (2016). Stanford Education Data Archive: Technical Documentation. Retrieved from:

https://cepa.stanford.edu/sites/default/files/SEDA\%20Technical\%20Documentation\%20

Version1_1.pdf

Vincent, C.G., Sprague, J.R., Pavel, M., Tobin, T.J., \& Gau, J.M. (2015). Effectiveness of schoolwide positive behavior interventions and supports in reducing racially inequitable disciplinary exclusion. In D. J. Losen (Ed.), Closing the School Discipline Gap: Equitable Remedies for Excessive Exclusion. (pp. 207-221). New York, NY: Teachers College Press.

Welch, K., \& Payne, A. A. (2012). Exclusionary school punishment: The effect of racial threat on expulsion and suspension. Youth Violence and Juvenile Justice, 10(2), 155-171. 
Table 1: Descriptive statistics: Overall, and every third sample: 1980-2006

\begin{tabular}{|c|c|c|c|c|c|c|c|c|c|c|c|c|}
\hline & \multicolumn{2}{|c|}{$1980-2006$} & \multicolumn{2}{|c|}{1980} & \multicolumn{2}{|c|}{1986} & \multicolumn{2}{|c|}{1992} & \multicolumn{2}{|c|}{1998} & \multicolumn{2}{|c|}{2004} \\
\hline & Mean & S.D. & Mean & S.D. & Mean & S.D. & Mean & S.D. & Mean & S.D. & Mean & S.D. \\
\hline Proportion of Students Receiving Corporal Punishment & 0.028 & 0.064 & 0.036 & 0.062 & 0.028 & 0.058 & 0.019 & 0.053 & 0.025 & 0.07 & 0.016 & 0.054 \\
\hline School District Did Not Use Corporal Punishment & 0.612 & 0.487 & 0.392 & 0.488 & 0.491 & 0.500 & 0.719 & 0.449 & 0.719 & 0.450 & 0.781 & 0.414 \\
\hline Proportion of Students Suspended & 0.048 & 0.053 & 0.040 & 0.044 & 0.042 & 0.045 & 0.037 & 0.043 & 0.061 & 0.061 & 0.054 & 0.062 \\
\hline Proportion of White Students Suspended & 0.042 & 0.047 & 0.037 & 0.042 & 0.039 & 0.043 & 0.032 & 0.040 & 0.052 & 0.053 & 0.044 & 0.050 \\
\hline Proportion of Black Students Suspended & 0.082 & 0.113 & 0.061 & 0.094 & 0.065 & 0.098 & 0.078 & 0.118 & 0.104 & 0.126 & 0.091 & 0.123 \\
\hline Proportion of Hispanic Students Suspended & 0.046 & 0.086 & 0.032 & 0.069 & 0.039 & 0.081 & 0.041 & 0.078 & 0.060 & 0.092 & 0.049 & 0.079 \\
\hline Total Number of Schools in the District & 10 & 27 & 10 & 26 & 11 & 28 & 9 & 27 & 11 & 27 & 9 & 30 \\
\hline Total Student Enrollment & 5688 & 21723 & 5620 & 20247 & 6910 & 24515 & 5313 & 22091 & 6271 & 22684 & 5424 & 23413 \\
\hline Proportion of All Students that are Native American & 0.025 & 0.106 & 0.015 & 0.080 & 0.043 & 0.147 & 0.025 & 0.107 & 0.026 & 0.101 & 0.031 & 0.117 \\
\hline Proportion of All Students that are Asian & 0.014 & 0.035 & 0.009 & 0.023 & 0.015 & 0.034 & 0.014 & 0.035 & 0.019 & 0.043 & 0.019 & 0.042 \\
\hline Proportion of All Students that are Hispanic & 0.076 & 0.165 & 0.053 & 0.143 & 0.058 & 0.153 & 0.057 & 0.138 & 0.083 & 0.163 & 0.100 & 0.180 \\
\hline Proportion of All Students that are Black & 0.105 & 0.194 & 0.091 & 0.179 & 0.092 & 0.178 & 0.086 & 0.179 & 0.111 & 0.190 & 0.100 & 0.189 \\
\hline Proportion of All Students that are White & 0.779 & 0.260 & 0.832 & 0.234 & 0.793 & 0.261 & 0.818 & 0.242 & 0.762 & 0.256 & 0.749 & 0.272 \\
\hline Proportion of All Students that are Male & 0.516 & 0.036 & 0.514 & 0.018 & 0.515 & 0.021 & 0.517 & 0.042 & 0.518 & 0.043 & 0.518 & 0.044 \\
\hline Proportion of All Students that are Female & 0.484 & 0.036 & 0.486 & 0.018 & 0.485 & 0.021 & 0.483 & 0.042 & 0.482 & 0.043 & 0.482 & 0.044 \\
\hline Observations & 59040 & & 5050 & & 3370 & & 4670 & & 5040 & & 4730 & \\
\hline
\end{tabular}

Notes. Means and standard deviations reported. Observations are school district-years. The number of observations for the racial suspension rates vary as not all districts had students from each race enrolled. Sample sizes rounded to nearest 10 in compliance with IES restricted data standards. Enrollment numbers rounded to nearest whole student. 
Table 2: Coefficients and standard errors from regressions predicting overall district suspension rate from "de facto" corporal punishment ban indicator and from district corporal punishment rate

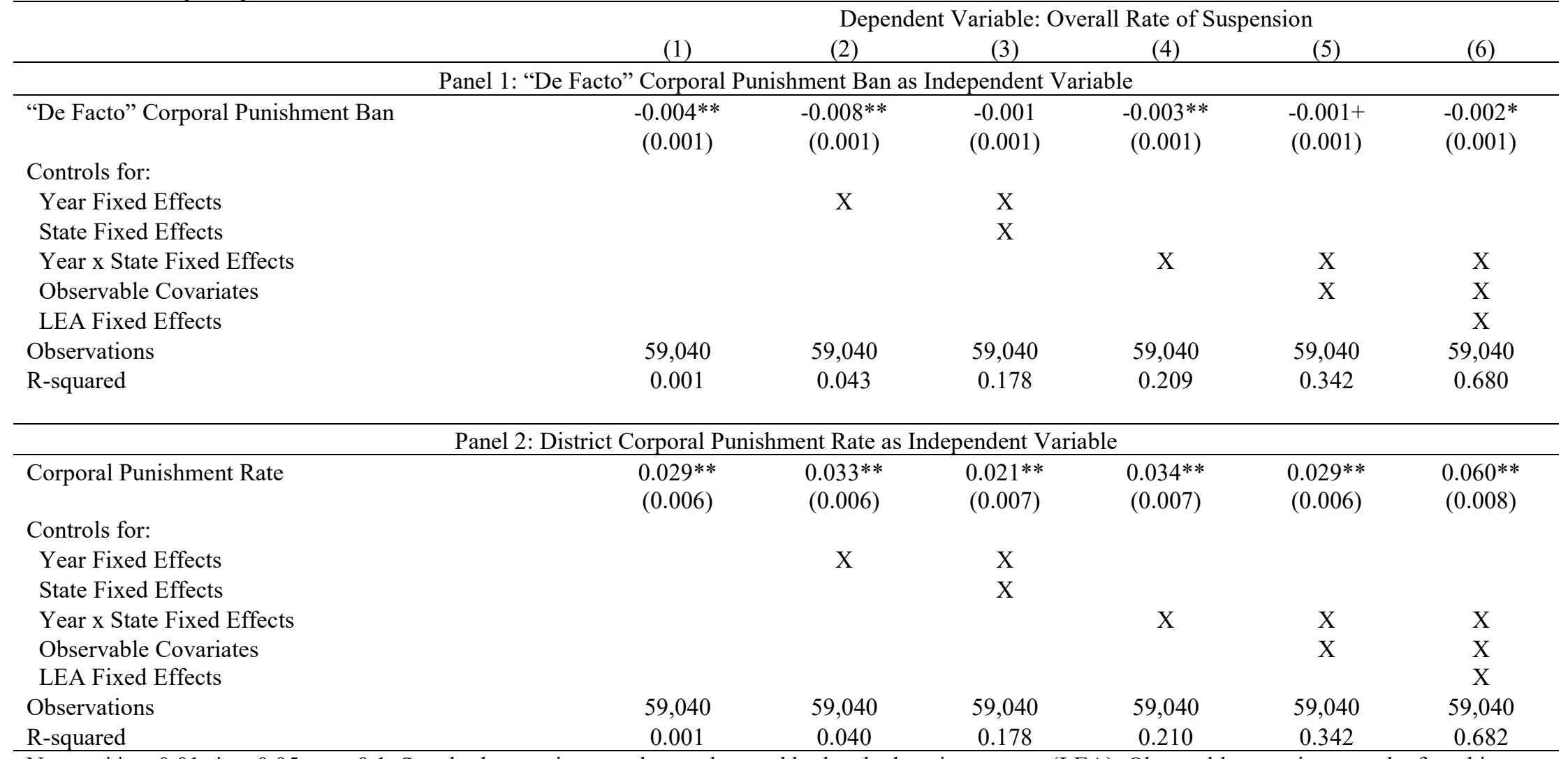

Notes: ${ }^{* *} \mathrm{p}<0.01, * \mathrm{p}<0.05,+\mathrm{p}<0.1$; Standard errors in parentheses clustered by local education agency (LEA); Observable covariates can be found in Table 1 
Table 3: Coefficients and standard errors from regressions predicting district suspension rate for racial/ethnic subgroups from "de facto" corporal punishment ban indicator and district corporal punishment rate
(1)
$(2)$
(3)
(4)
(5)
(6)
(7)
(8)

Dependent Variable:

Overall Suspension Rate White Suspension Rate Black Suspension Rate

Hispanic Suspension

\begin{tabular}{|c|c|c|c|c|c|c|}
\hline Dependent Variable: & Overall Suspension Rate & White Suspension Rate & Black S & sion Rate & \multicolumn{2}{|c|}{ Rate } \\
\hline & \multicolumn{6}{|c|}{ Panel 1: "De Facto" Corporal Punishment Ban as Independent Variable } \\
\hline "De Facto" Corporal Punishment Ban & $\begin{array}{c}-0.001+ \\
(0.001)\end{array}$ & $\begin{array}{c}-0.003 * * \\
(0.001)\end{array}$ & $\begin{array}{l}-0.000 \\
(0.002)\end{array}$ & $\begin{array}{l}-0.003 \\
(0.002)\end{array}$ & $\begin{array}{c}0.001 \\
(0.001)\end{array}$ & $\begin{array}{l}-0.000 \\
(0.001)\end{array}$ \\
\hline
\end{tabular}

Controls for:

Observable Covariates

State x Year Fixed Effects

LEA Fixed Effects

Observations

$\begin{array}{ll}X & X \\ X & X\end{array}$

$\mathrm{R}$-squared

$0.342 \stackrel{59,040}{ } 0.680$

$\begin{array}{lll}X & & X \\ X & & X \\ & & X \\ & 57,460 & \end{array}$

$\begin{array}{ll}\mathrm{X} & \mathrm{X} \\ \mathrm{X} & \mathrm{X}\end{array}$

$\mathrm{X}$
$\mathrm{X}$

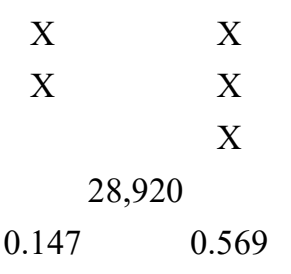

Corporal Punishment Rate
Controls for:
Observable Covariates
State x Year Fixed Effects
LEA Fixed Effects

Observations

\begin{tabular}{ccc} 
& \multicolumn{2}{c}{ Panel 2: District Corp } \\
$0.029 * *$ & $0.060^{* *}$ & $0.029 * *$ \\
$(0.006)$ & $(0.008)$ & $(0.005)$
\end{tabular}

0.624

0.207

31,250

0.594

\begin{tabular}{ccccc}
\multicolumn{5}{c}{ oral Punishment Rate as Independent Variable } \\
$0.044^{* *}$ & $0.042 * *$ & $0.095 * *$ & -0.000 & 0.014 \\
$(0.007)$ & $(0.012)$ & $(0.016)$ & $(0.009)$ & $(0.013)$
\end{tabular}

R-squared

\begin{tabular}{|c|c|c|c|c|c|c|c|}
\hline $\mathrm{X}$ & $\mathrm{X}$ & $X$ & $X$ & $X$ & $X$ & $X$ & $X$ \\
\hline \multirow[t]{2}{*}{$X$} & $X$ & $X$ & $X$ & $\mathrm{X}$ & $X$ & $X$ & $\mathrm{X}$ \\
\hline & $X$ & & $X$ & & $X$ & & $X$ \\
\hline \multicolumn{2}{|c|}{59,040} & \multicolumn{2}{|c|}{57,460} & \multicolumn{2}{|c|}{31,250} & \multicolumn{2}{|c|}{28,920} \\
\hline 0.342 & 0.682 & 0.238 & 0.625 & 0.207 & 0.595 & 0.147 & 0.569 \\
\hline
\end{tabular}

Notes: $* * \mathrm{p}<0.01, * \mathrm{p}<0.05,+\mathrm{p}<0.1$; Standard errors in parentheses clustered by local education agency (LEA); Observable covariates can be found in Table 1 ; Sample for each subgroup limited to districts with a minimum of 20 students of the racial/ethnic subgroup 
Table 4: Coefficients and standard errors from regressions predicting district suspension rate for racial/ethnic subgroups from "de facto" corporal punishment ban indicator and district corporal punishment rate interacted with school racial/ethnic composition

(4)

(5)

(6)

(7)
Hispanic Suspension
Rate

Dependent Variable Overall Suspension Rat Panel 1: "De Facto" Corporal Punishment Ban as Independent Variable

\begin{tabular}{|c|c|c|c|c|c|c|c|c|}
\hline \multirow[t]{2}{*}{ "De Facto" Corporal Punishment Ban } & $-0.008 * *$ & $-0.006^{* *}$ & $-0.007 * *$ & $-0.004 * *$ & $-0.018 * *$ & $-0.009 * *$ & -0.002 & -0.001 \\
\hline & $(0.001)$ & $(0.001)$ & $(0.001)$ & $(0.001)$ & $(0.003)$ & $(0.003)$ & $(0.002)$ & $(0.002)$ \\
\hline \multirow[t]{2}{*}{ "De Facto" Ban * Proportion of Black Students } & $0.049 * *$ & $0.029 * *$ & $0.023 * *$ & 0.005 & $0.069 * *$ & $0.025 * *$ & $0.013+$ & 0.003 \\
\hline & $(0.006)$ & $(0.007)$ & $(0.005)$ & $(0.007)$ & $(0.008)$ & $(0.009)$ & $(0.007)$ & $(0.010)$ \\
\hline \multirow[t]{2}{*}{ "De Facto" Ban * Proportion of Hispanic Students } & $0.015 * *$ & $0.009^{*}$ & $0.018 * *$ & 0.006 & $0.034 * *$ & 0.002 & $0.009^{*}$ & -0.000 \\
\hline & $(0.003)$ & $(0.004)$ & $(0.004)$ & $(0.004)$ & $(0.010)$ & $(0.010)$ & $(0.004)$ & $(0.005)$ \\
\hline
\end{tabular}

Controls for:

\section{Observable Covariates}

State x Year Fixed Effects

LEA Fixed Effects

Observations

R-squared

$\begin{array}{llll}X & X & X & X \\ X & X & X & X \\ & X & & X\end{array}$

57,460

$\mathrm{X} \quad \mathrm{X}$

$0.239 \quad 0.624$

.624

$\mathrm{X}$
$\mathrm{X}$

$\begin{array}{ll}X & X \\ X & X \\ & X\end{array}$

31,250

$\begin{array}{ll}X & X \\ X & X \\ & X\end{array}$

28,920

$\begin{array}{llll}0.213 & 0.594 & 0.147 & 0.569\end{array}$

\begin{tabular}{|c|c|c|c|c|c|c|c|c|}
\hline \multirow[b]{2}{*}{ Corporal Punishment Rate } & \multicolumn{8}{|c|}{ Panel 2: District Corporal Punishment Rate as Independent Variable } \\
\hline & $0.081 * *$ & $0.069 * *$ & $0.062 * *$ & $0.049 * *$ & $0.167 * *$ & $0.139 * *$ & 0.017 & 0.019 \\
\hline & $(0.008)$ & $(0.010)$ & $(0.007)$ & $(0.010)$ & $(0.020)$ & $(0.030)$ & $(0.016)$ & $(0.020)$ \\
\hline \multirow[t]{2}{*}{ Corporal Punishment Rate * Proportion of Black Students } & $-0.169 * *$ & -0.013 & $-0.103 * *$ & -0.014 & $-0.299 * *$ & -0.085 & -0.068 & -0.028 \\
\hline & $(0.027)$ & $(0.039)$ & $(0.025)$ & $(0.037)$ & $(0.042)$ & $(0.060)$ & $(0.065)$ & $(0.075)$ \\
\hline \multirow[t]{2}{*}{ Corporal Punishment Rate * Proportion of Hispanic Students } & $-0.128 * *$ & $-0.091 * *$ & $-0.116^{* *}$ & -0.031 & $-0.308 * *$ & $-0.228 *$ & -0.020 & 0.003 \\
\hline & $(0.024)$ & $(0.034)$ & $(0.026)$ & $(0.038)$ & $(0.068)$ & $(0.100)$ & $(0.033)$ & $(0.044)$ \\
\hline \multicolumn{9}{|l|}{ Controls for: } \\
\hline Observable Covariates & $\mathrm{X}$ & $\mathrm{X}$ & $\mathrm{X}$ & $\mathrm{X}$ & $\mathrm{X}$ & $\mathrm{X}$ & $\mathrm{X}$ & $\mathrm{X}$ \\
\hline State $\mathrm{x}$ Year Fixed Effects & $\mathrm{X}$ & $\mathrm{X}$ & $\mathrm{X}$ & $\mathrm{X}$ & $\mathrm{X}$ & $\mathrm{X}$ & $\mathrm{X}$ & $\mathrm{X}$ \\
\hline LEA Fixed Effects & & $\mathrm{X}$ & & $\mathrm{X}$ & & $\mathrm{X}$ & & $\mathrm{X}$ \\
\hline Observations & \multicolumn{2}{|c|}{59,040} & \multicolumn{2}{|c|}{57,460} & \multicolumn{2}{|c|}{31,250} & \multicolumn{2}{|c|}{28,920} \\
\hline R-squared & 0.345 & 0.682 & 0.239 & 0.625 & 0.211 & 0.595 & 0.147 & 0.569 \\
\hline
\end{tabular}

Notes: $* * \mathrm{p}<0.01, * \mathrm{p}<0.05,+\mathrm{p}<0.1$; Standard errors in parentheses clustered by local education agency (LEA); Observable covariates can be found in Table 1 ; Sample for each subgroup limited to districts with a minimum of 20 students of the racial/ethnic subgroup 
Mechanism 1: Changes in Behavior
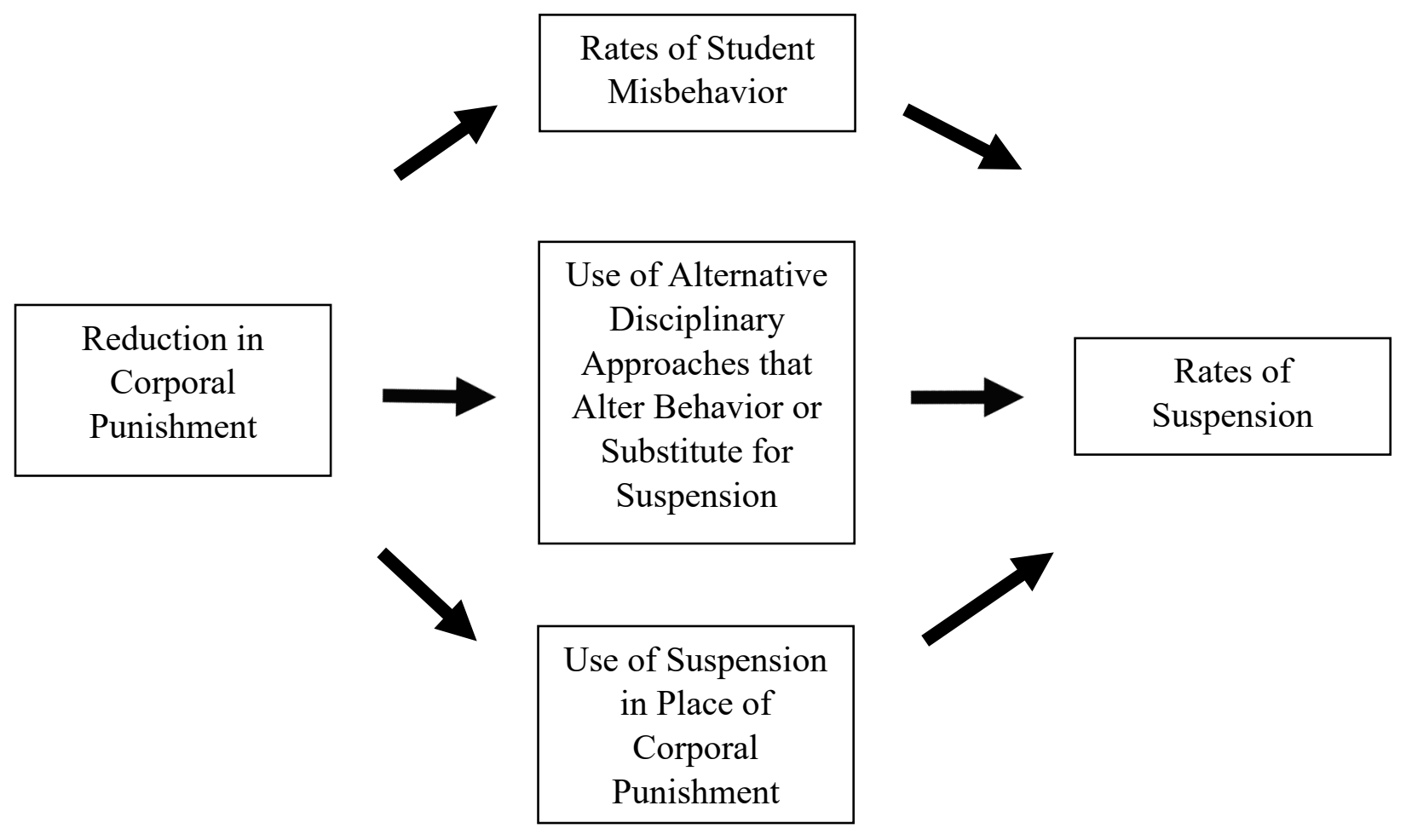

Mechanism 2: Substitution of One Form of Discipline for Another

Figure 1: Theory of Change for Relationship between Corporal Punishment Use Reductions and Suspension Rates 
Appendix Table A1: States with Corporal Punishment Bans in Public Schools

\begin{tabular}{|lc|lc|}
\hline \multicolumn{1}{|c|}{ State } & Ban Start Year & \multicolumn{1}{c|}{ State } & Ban Start Year \\
\hline Alaska & 1989 & New Jersey & 1867 \\
California & 1986 & New Mexico & 2011 \\
Connecticut & 1989 & New York & 1985 \\
Delaware & 2003 & North Dakota & 1989 \\
Hawaii* & 1973 & Ohio & 2009 \\
Illinois & 1994 & Oregon & 1989 \\
Iowa & 1989 & Pennsylvania & 2005 \\
Maine & 1975 & Rhode Island* & 2002 \\
Maryland & 1993 & South Dakota* & 1990 \\
Massachusetts & 1972 & Utah & 1992 \\
Michigan & 1989 & Vermont & 1985 \\
Minnesota & 1989 & Virginia & 1989 \\
Montana & 1991 & Washington & 1993 \\
Nebraska & 1988 & West Virginia & 1994 \\
Nevada & 1993 & Wisconsin & 1988 \\
New Hampshire* & 1983 & & \\
\hline
\end{tabular}

Notes. We created this table by comparing the years of state corporal punishment bans as listed by Thomson Reuters (n.d.) and Gundersen Center for Effective Discipline (n.d.). Using Education Week (2016) as a starting point to locate the state laws, we then tried to independently verify the laws and the year of their adoption by reading the relevant section of each state's code. When necessary we contacted the legal department of the state board of education.

*Discrepancies exist as to when the state ban started. This could mean that our sources listed start dates that differed from each other, and we could not independently verify which was correct, that they listed the same start date but that it conflicted with what we found in the state codes, or that the language of the "ban" included loopholes big enough to make us question if it was truly a ban. Further details and documentation of state laws are available upon request. 
Appendix B: Graphical representations of corporal punishment use by state with ban year
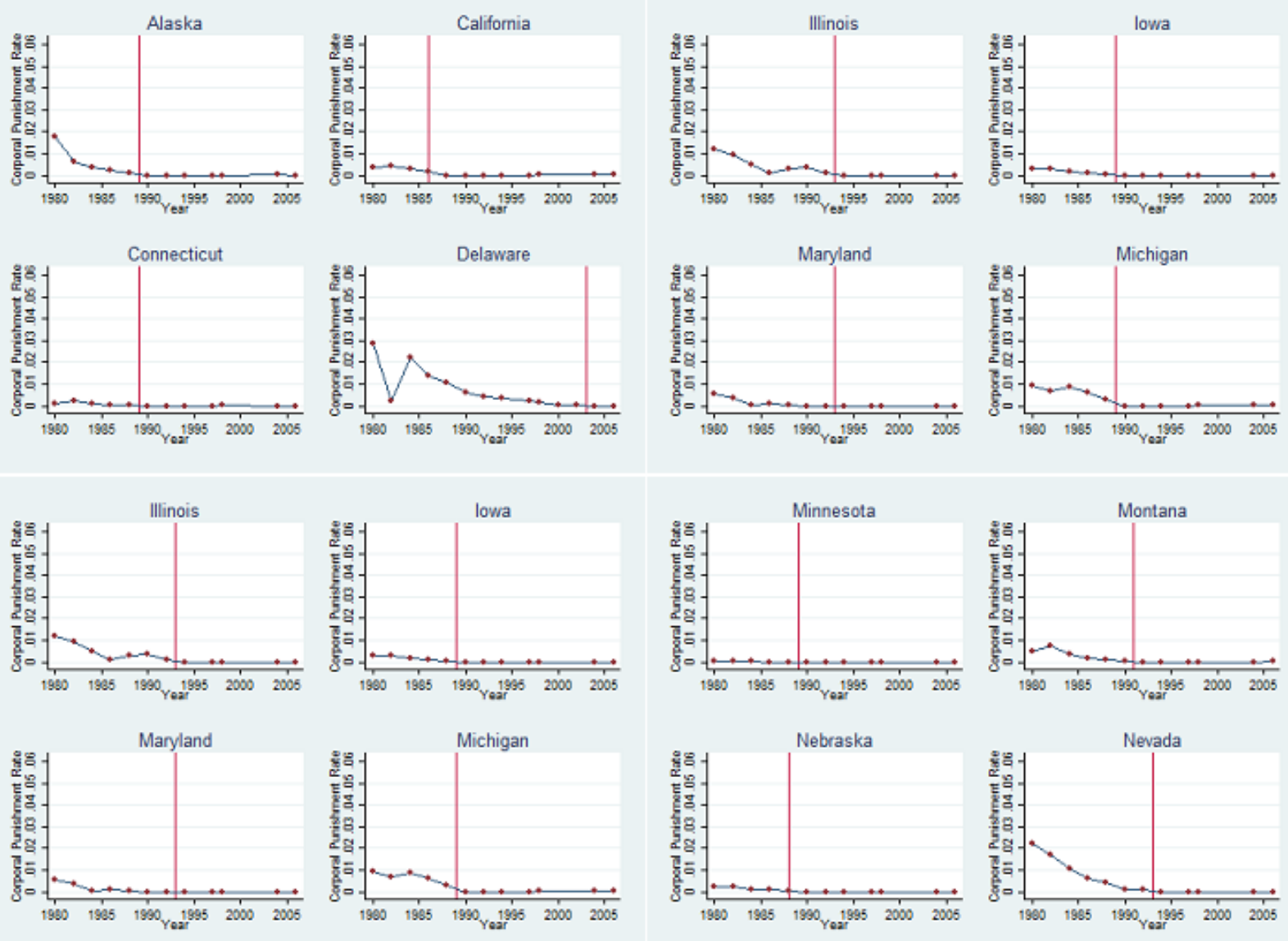

Appendix Figure B1: Corporal punishment rates and state ban years, 1980-2006

Notes. The vertical line represents the start of the state-wide legislative ban; Data is from the 1980-2006 iterations of the CRDC. Corporal punishment rates are the proportion of students in a district receiving corporal punishment in a given year. 

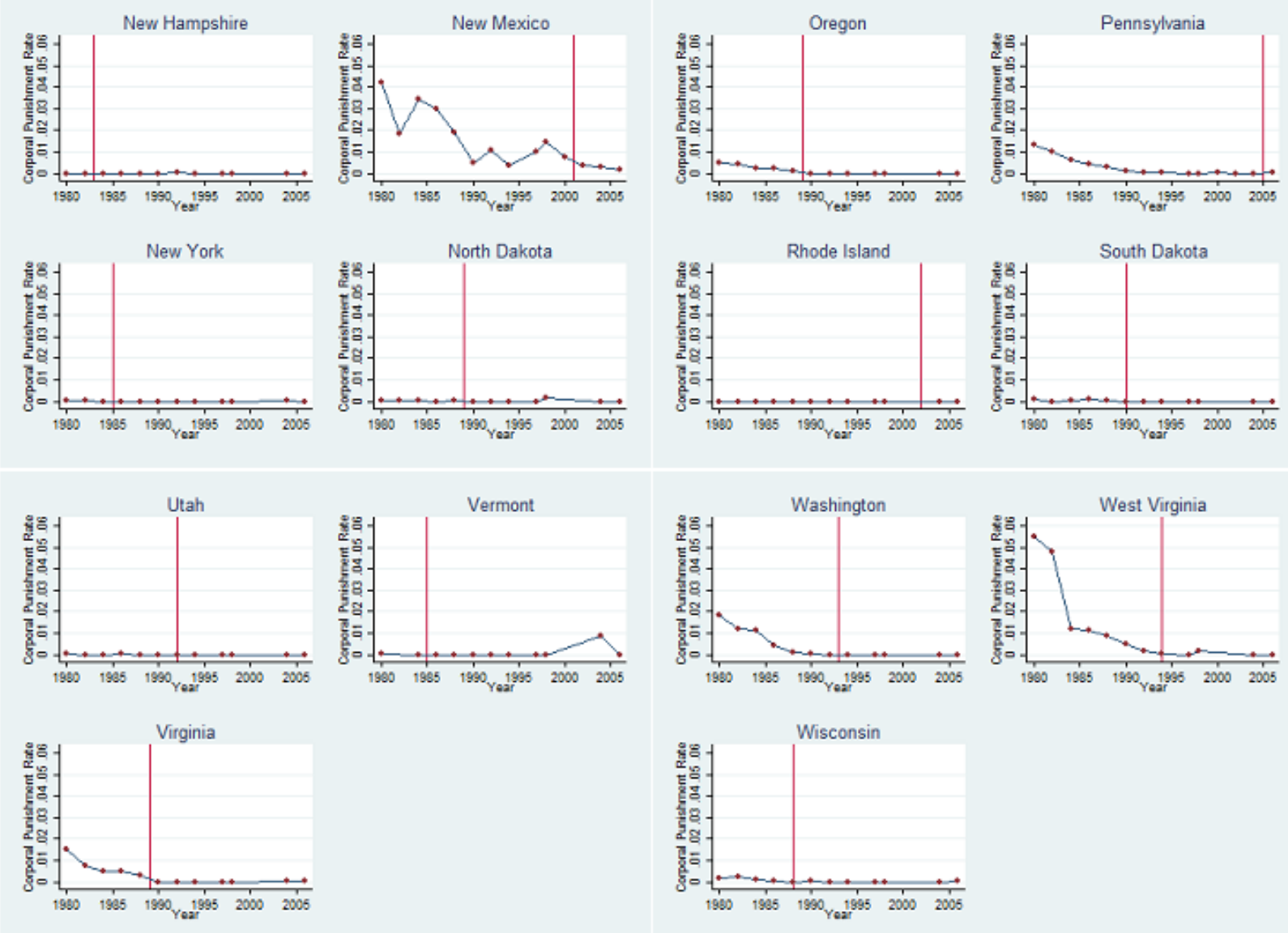

Appendix Figure B2: Corporal punishment rates and state ban years, 1980-2006

Notes. The vertical line represents the start of the state-wide legislative ban; Data is from the 1980-2006 iterations of the CRDC. Corporal punishment rates are the proportion of students in a district receiving corporal punishment in a given year. 